\title{
IMPLEMENTASI ALGORITMA C4.5 UNTUK PENGOLAHAN DATA HUTAN LINDUNG (STUDI KASUS: DINAS KEHUTANAN SUMATERA UTARA)
}

\author{
Yolanda Angelita S \\ Program Studi Teknik Informatika STMIK Budi Darma, Medan, Indonesia \\ Email: Yolandaangelita16@gmail.com,
}

\begin{abstract}
Abstrak
Data Mining merupakan suatu penemuan informasidengan melakukan penggalian pola informasi yang berisi pencarian trend dalam sejumlah data yang sangat besar serta membantu proses penyimpanan data dalam mengambil suatu keputusan diwaktu yang akan datang. Dalam menentukan pola dilakukan teknik klasifikasi mengumpulkan record (Training set). Hutan merupakan peranan yang sangat penting bagi pembangunan bangsa dan negara. Karna Hutan dapat memberikan manfaat yang sebesar-besarnya. Namun, keadaan Hutan Lindung saat ini telah mengalami penurunan luas yang drastis, untuk itu dengan memanfaatkan data Hutan Lindung dapat menghasilkan informasi tentang Hutan Lindung yang menjadi prioritas dan yang tidak prioritas untuk di Reboisasi atau ditangani terlebih dahulu sehingga fungsi hutan benar pada penggunaannya. Algoritma C4.5 atau biasa dikenal dengan metode pohon keputusan dapat memberikan informasi rule data untuk menggambarkan proses yang terkait dengan pengolahan data hutan lindung. Karakteristik data yang diklasifikasi dapat di peroleh dengan jelas, baik dalam bentuk struktur pohon keputusan maupun dalam bentuk aturan. Sehingga dalam tahap pengujian dengan software Tanagra 1.4 dapat membantu dalam mengolah data Hutan Lindung yang valid.
\end{abstract}

Kata Kunci: Data Mining, Hutan Lindung, Algoritma C4.5, Tanagra Versi 1.4

\section{Abstract}

Data Mining is an information discovery by extracting information patterns that contain trend searches in a very large amount of data and assist the process of storing data in making a decision in the future. In determining the pattern classification techniques are done collecting records (Training set).Forests are a very important role for national and state development. Because forests can provide maximum benefits. However, the current situation of Protected Forest has experienced a drastic reduction in area, for that reason utilizing Protected Forest data can produce information about Protected Forest that is a priority and which is not a priority to be reforested or handled first so that the forest function is correct in its use.C4.5 algorithm or commonly known as the decision tree method can provide rule data information to describe the processes associated with processing protected forest data. The characteristics of the classified data can be obtained clearly, both in the form of decision tree structures and in the form of rules. So that in the testing phase with Tanagra 1.4 software can assist in processing valid Protection Forest data.

Keywords: Data Mining, Protection Forest, C4.5 Algorithm, Tanagra Version 1.4

\section{PENDAHULUAN}

Hutan lindung adalah kawasan hutan yang mempunyai fungsi pokok sebagai perlindungan sistem penyangga kehidupan untuk mengatur tata air, mencegah banjir, mengendalikan erosi, mencegah intrusi air laut, dan memelihara kesuburan tanah. Hutan lindung Indonesia memiliki peranan penting dalam menjaga ekosistem dunia. Pengertian hutan lindung secara umum adalah hutan atau tanah luas yang berisikan jenis flora dan fauna yang terbentuk secara alamiah maupun tidak. Karna hutan dapat memberikan manfaat yang besar bagi kemakmuran dan kesejahteraan rakyat. Negara Indonesia termasuk hutan terluas ketiga setelah Brazil dan Zaire dalam melindungi ekosistem lokal, nasional, regional dan global yang sudah diakui secara luas. Berdasarkan SK MENLHK NO.SK.1076 Tahun 2017 Tentang perkembangan pengukuhan kawasan hutan Provinsi Sumatera Utara s/d 2016 memiliki luas hutan \pm 3.010.160,89 Ha. Dengan lahan kritis yang dibagi menjadi: sangat kritis, kritis, agak kritis, potensial kritis[1].

Berdasarkan uraian diatas, membuktikan bahwa betapa pentingnya pengolahan hutan yang baik termasuk hutan lindung. Saat ini, keadaan hutan lindung telah mengalami penurunan luas dan kerusakan hutan lindung yang diakibatkan oleh penebangan liar yang berskala besar. Jika hal tersebut tidak segera ditangani maka akan menimbulkan berbagai masalah misalnya, banjir, longsor, ataupun erosi, dan jika hal tersebut terjadi maka spesies flora dan fauna yang berada dikawasan hutan lindung akan terancam punah. Untuk itu, tata kelola hutan lindung sangat diperlukan dalam hal pengolahan data hutan lindung dalam mencapai hutan lindung yang baik dan juga kelestariannya. Dan kerusakan hutan lindung diatas disebabkan beberapa faktor diantaranya adalah penebangan liar. Hal pertama yang dapat dilakukan untuk menanggulanginya adalah mengumpulkan data penyebab kerusakan hutan lindung, kemudian data yang terkumpul tersebut diolah untuk mendapatkan hasil hutan lindung mana yang akan mendapatkan penanganan terlebih dahulu berdasrkan keadaan, kondisi serta faktor yang paling kritis penyebab kerusakan hutan lindung.

Data Mining adalah serangkaian proses untuk menggali nilai tambah berupa informasi yang selama ini tidak diketahui secara manual dari suatu basis data dengan melakukan penggalian pola-pola dari data dengan tujuan untuk memanipulasi data menjadi informasi yang lebih berharga yang diperoleh dengan cara mengekstraksi dan mengenali 
pola yang penting atau menarik dari data yang terdapat dalam basis data. Algoritma C 4.5 suatu algoritma yang digunakan untuk menghasilkan suatu pohon keputusan yang mampu mengklasifikasi suatu obyek. C 4.5. Dimana didalam proses pengerjaan menghitung nilai gain dan entropy terhadap atribut - atribut data yang telah disajikan oleh basis data sebelumnya. Dari proses klasifikasi dan hasil yang didapatkan digambarkan dalam bentuk pohon keputusan dan berdasarkan pohon keputusan tersebut didapatkanlah sebuah informasi baru yang berasal dari basis data sebelumnya dalam bentuk aturan - aturan atau rule.

Pada penelitian terdahulu oleh Beti Novianti yang berjudul Implementasi Data Mining Dengan Algoritma C4.5 Untuk Penjurusan Siswa (Studi Kasus: SMA Negeri 1 Pontianak) di Fakultas MIPA Universitas Tanjungpura mengatakan "Algoritma $\mathrm{C} 4.5$ berhasil diterapkan untuk aplikasi klasifikasi penjurusan siswa dengan algoritma pohon keputusan C4.5 dapat mengklasifikasi penjurusan siswa. Dari hasil klasifikasi berupa pohon keputusan tersebut dapat digunakan untuk hasil penilaian tingkat kinerja hasil klasifikasi penjurusan siswa"[2].Penulis melakukan penelitian dengan tujuan untuk pengolaan hutan lindung dapat diprediksi atau dapat dikelola data yang lama sampai data terbaru guna untuk mempermudah atau meningkatkan tingkat kinerja Dinas Kehutanan Sumatera Utara dalam pengolahan data hutan lindung.

\section{TEORITIS}

\subsection{Algoritma C4.5}

Algoritma C4.5 diperkenalkan oleh Quinlan (1996) sebagai versi perbaikan dari ID3. Dalam ID3, induksi decision tree hanya bisa dilakukan pada fitur bertipe kategorikal (nominal atau ordinal), sedangkan tipe numerik (interval atau rasio) tidak dapat digunakan. Perbaikan yang membedakan algoritma C4.5 dari ID3 adalah dapat menangani fitur dengan tipe numerik, melakukan pemotongan (prunning)decision tree, dan penurunan (deriving)rule set. Algoritma C4.5 juga menggunakan kriteria gain dalam menentukan fitur yang menjadi pemecah node pada pohon yang diinduksi [4].Yang menjadi hal penting dalam induksi decision tree adalah bagaimana menyatakan syarat pengujian pada node. Ada 3 kelompok penting dalam syarat pengujian node.

1. Fitur Biner

Fitur yang hanya mempunyai dua nilai berbeda disebut dengan fitur biber. Syarat pengujian ketika fitur ini menjadi node (akar maupun internal) hanya punya dua pilihan cabang. Contoh pemecahan fitur biner pada gambar 3.1 .

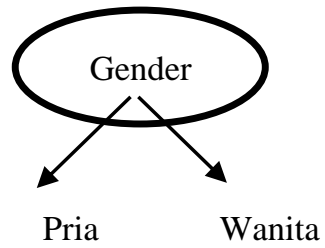

Gambar 1. Syarat pengujian fitur biner

Di dalam penyelesaian sebuah kasus menggunakan algoritma C4.5 ada 2 (dua) elemen yang harus dipahami yaitu:

1. Entropy

2. Gain

Secara umum algoritma C4.5 untuk membangun pohon keputusan adalah sebagai berikut.

a. Pilih atribut sebagai akar

b. Buat cabang untuk tiap-tiap nilai

c. Bagi kasus dalam cabang

d. Ulangi proses untuk setiap cabang sampai semua kasus pada cabang memiliki kelas yang sama.

Untuk memilih atribut sebagai akar, didasarkan pada nilai gain tertinggi dari atribut-atribut yang ada. Untuk menghitung gain digunakan, rumus seperti pada persamaan berikut [3]:

Gaint $(S, A)=$ Entropy $(S) \sum_{i=l}^{n} \frac{\left|S_{i}\right|}{|S|} *$

Keterangan:

S : Himpunan kasus

A : Atribut

n : Jumlah partisi atribut A

$\left|\mathrm{S}_{\mathrm{i}}\right| \quad$ : Jumlah kasus pada partisi ke $-\mathrm{i}$

| S | : Jumlah kasus dalam S

Sementara itu, perhitungan nilai entropy dapat dilihat pada persamaan berikut:

Entropy $(S)=\sum_{i=l}^{n}-p i^{*} \log _{2} p i$

Keterangan:

$\mathrm{S} \quad$ : Himpunan kasus

A : Fitur

n : Jumlah partisi 


\subsection{Data Mining}

Data mining dapat di definisikan sebagaiekstraksi suatu informasi atau pola yang penting atau menarik dari data yang ada di database yang besar. Data mining juga dikenal dengan nama Knowledge Discovery In Database (KDD). Proses data mining atau yang biasa disebut dengan Knowledge Discovery Databases (KDD). KDD sering kali digunakan secara bergantian untuk menjabarkan proses penggalian suatu informasi tersembunyi dalam suatu basis data yang besar. Sebenarnya kedua istilah tersebut mempunyai konsep yang berbeda, akan tetapi berkaitan satu dengan yang lain.

\subsection{Hutan Lindung}

Pengelolaan sumber daya alam khususnya sumber daya hutan adalah upaya pengelolaan sumber daya alam yang terkandung pada kawasan hutan. Hal tersebut dilakukan melalui pembagian kawasan hutan berasarkan fungsi hutan, konservasi dan produksi dengan memperhitungkan kelangsungan persediannya dan lingkungan sekitar. Pengelolaan hutan yang lestari perlu didukung dengan manajemen kawasan yang terarah dan pasti.

Hutan lindung adalah suatu kawasan yang sudah ditetapkan pemerintah atau kelompok masyarakat tertentu untuk dilindungi. Hutan lindung atau protectionforest memiliki fungsi ekologis terutama sebagai sumber air dan mempertahankan kesuburan tanah bagi hutan termasuk masyarakat disekitar hitan lindung. Menurut Undang-undang No. 41 tahun 1999 bahwa hutan lindung adalah kawasan hutan yang mempunyai fungsi pokok sebagai perlindungan sistem penyangga kehidupan untuk mengatur tata air, mencegah banjir, mengendalikan erosi, mencegah instrusi air laut dan memelihara kesuburan tanah[7].

\section{ANALISA DAN PEMBAHASAN}

Analisa merupakan suatu pengamatan dari suatu informasi secara detail dengan cara menguraikan ke dalam bagian komponen yang bertujuan untuk mengidentifikasi dan mengevaluasi permasalahan atau hambatan yang di temui, sehingga informasi yang diperoleh lebih tepat secara keseluruhan. Hutan lindung merupakan suatu kawasan hutan yang di tetapkan oleh pemerintah dan masyarakat untuk dilindungi. Sebagian besar setiap orang telah mengetahui fungsi besar dari hutan lindung yaitu sebagai perlindungan sistem penyangga kehidupan untuk mengatur tata air, mencegah banjir, mengendalikan erosi, dan memelihara kesuburan tanah. Namun, saat ini keadaan hutan lindung sudah mulai tidak terawat, penurunan luas hutan lindung serta kerusakan dimana-mana yang diakibatkan oleh penebangan liar yang berskala besar. Jika, hal tersebut masih berkelanjutan maka dapat menimbulkan berbagai masalah seperti, banjir, longsor, ataupun erosi, bahkan kemungkinan besar spesies flora dan fauna yang berada dikawasan hutan lindung akan terancam punah.

Oleh karena itu dibutuhkan proses pengolahan data hutan lindung secara baik dan juga benar, salah satu cara untuk mengolah data tersebut adalah dengan menerapkan atau menggunakan teknik datamining. Dimana data miningadalah proses analisa data yang besar menjadi informasi untuk menentukan pola dari kesimpulan data yang di analisa. Dengan menggunakan Algoritma C4.5 akan menggali data yang telah ada dan membentuk suatu pohon keputusan, dimana pohon keputusan ini yang akan diambil pola keputusan dan membantu instansi untuk mengetahui pengelompokan dan pengolahan hutan lindung agar tidak berdampak berdampak bagi tempat sekitar hutan lindung.

Sistem yang digunakan dalam klasifikasi penyebab pengolahan hutan lindung yaitu dengan menggunakan data awal numeric dan nonnumeric yang akan dibagi melalui atribut-atribut untuk memudahkan analisa berikutnya, kemudian setelah semua data yang dibagi melalui atributnya maka akan dilakukan proses klasifikasi dengan membuat pohon keputusan sebagai output. Proses pengambilan keputusan untuk mengklasifikasi penyebab pengelompokan pengolahan hutan lindung yang menjadi keputusan adalah berdasarkan lahan kritis hutan lindung.

Atribut merupakan kolom data yang menunjukkan fungsinya sebagai pembentuk karakteristik yang mempunyai nilai, kategori, maupun kode untuk setiap basis data. Berikut yang merupakan keterangan atribut dalam pengolahan data hutan lindung yaitu:

1. Bahaya Erosi (BE)

Kelas tingkat bahaya erosi tanah hutan lindung di dominasi oleh kelas erosi tinggi, sedang dan rendah.

2. Kemiringan Lereng (KL)

Kelas kemiringan lereng hutan lindug diklasifikasikan menjadi kelas datar, landai, curam, dan sangat curam.

3. Produktivitas (Pro)

Merupakan aktivitas yang sedang berlangsung pada hutan lindung yang diklasifikasikan menjadi baik dan buruk.

4. Jarak Dengan Pemukiman (JR)

Merupakan jarak hutan lindung dengan sekitarnya seperti permukiman penduduk yang diklasifikasikan menjadi jauh, dekat, sedang.

5. Kerusakan $(\mathrm{Kr})$

Merupakan tingkat kerusakan yang telah dialami hutan lindung yang diklasifikasikan menjadi tinggi, sedang, rendah. 
Berikut adalah tabel pengolahan data Hutan Lindung di Provinsi Sumatera Utara dapat dilihat dibawah ini:

\begin{tabular}{|c|c|c|c|c|c|}
\hline Bahaya Erosi (BE) & $\begin{array}{l}\text { Kemiringan } \\
\text { Lereng (KL) }\end{array}$ & Produktitas (Pro) & $\begin{array}{c}\text { Jarak Dengan } \\
\text { Pemukiman (Jr) }\end{array}$ & \begin{tabular}{|c} 
Kerusakan \\
$(\mathrm{Kr})$
\end{tabular} & Hasil \\
\hline Sedang & Landai & Baik & Dekat & Sedang & Tidak \\
\hline Tinggi & Curam & Buruk & Sedang & Tinggi & Tidak \\
\hline Tinggi & Landai & Buruk & Jauh & Sedang & Prioritas \\
\hline Rendah & Curam & Baik & Dekat & Rendah & Prioritas \\
\hline Rendah & Curam & Baik & Sedang & Rendah & Tidak \\
\hline Sedang & Sangat Curam & Buruk & Sedang & Sedang & Prioritas \\
\hline Rendah & Sangat Curam & Buruk & Sedang & Sedang & Prioritas \\
\hline Sedang & Curam & Baik & Dekat & Rendah & Tidak \\
\hline Tinggi & Curam & Buruk & Dekat & Rendah & Prioritas \\
\hline Sedang & Sangat Curam & Baik & Dekat & Sedang & Tidak \\
\hline Sedang & Landai & Baik & Jauh & Rendah & Tidak \\
\hline Tinggi & Landai & Buruk & Sedang & Tinggi & Prioritas \\
\hline Rendah & Landai & Baik & \begin{tabular}{|l|} 
Jauh \\
\end{tabular} & Sedang & Tidak \\
\hline Sedang & Curam & Baik & Sedang & Sedang & Tidak \\
\hline Tinggi & Sangat Curam & Buruk & Dekat & Tinggi & Prioritas \\
\hline Sedang & Landai & Baik & Dekat & Sedang & Tidak \\
\hline Tinggi & Landai & Buruk & Jauh & Sedang & Prioritas \\
\hline Rendah & \begin{tabular}{|l} 
Curam \\
\end{tabular} & Baik & \begin{tabular}{|l} 
Dekat \\
\end{tabular} & Rendah & Prioritas \\
\hline Rendah & Curam & Baik & Sedang & Rendah & Tidak \\
\hline Sedang & Sangat Curam & Buruk & Sedang & Sedang & Prioritas \\
\hline Rendah & Sangat Curam & Buruk & Sedang & Sedang & Prioritas \\
\hline Sedang & Curam & Baik & Dekat & Rendah & Tidak \\
\hline Tinggi & Curam & Buruk & Dekat & Rendah & Prioritas \\
\hline Sedang & Sangat Curam & Baik & Dekat & Sedang & Tidak \\
\hline Sedang & Landai & Baik & Jauh & Rendah & Tidak \\
\hline Rendah & Landai & Baik & \begin{tabular}{|l|} 
Jauh \\
\end{tabular} & Sedang & Tidak \\
\hline Sedang & Curam & Baik & Sedang & Sedang & Tidak \\
\hline
\end{tabular}

Gambar 2. Data Hutan Lindung di Provinsi Sumatera Utara

Untuk mengimplementasikan metode C4.5 menggunakan tools tanagra versi 1.4 adapun hasil decission tree yang dihasilkan dari data sample dan atribute yang buat seperti pada gambar 3. berikut:

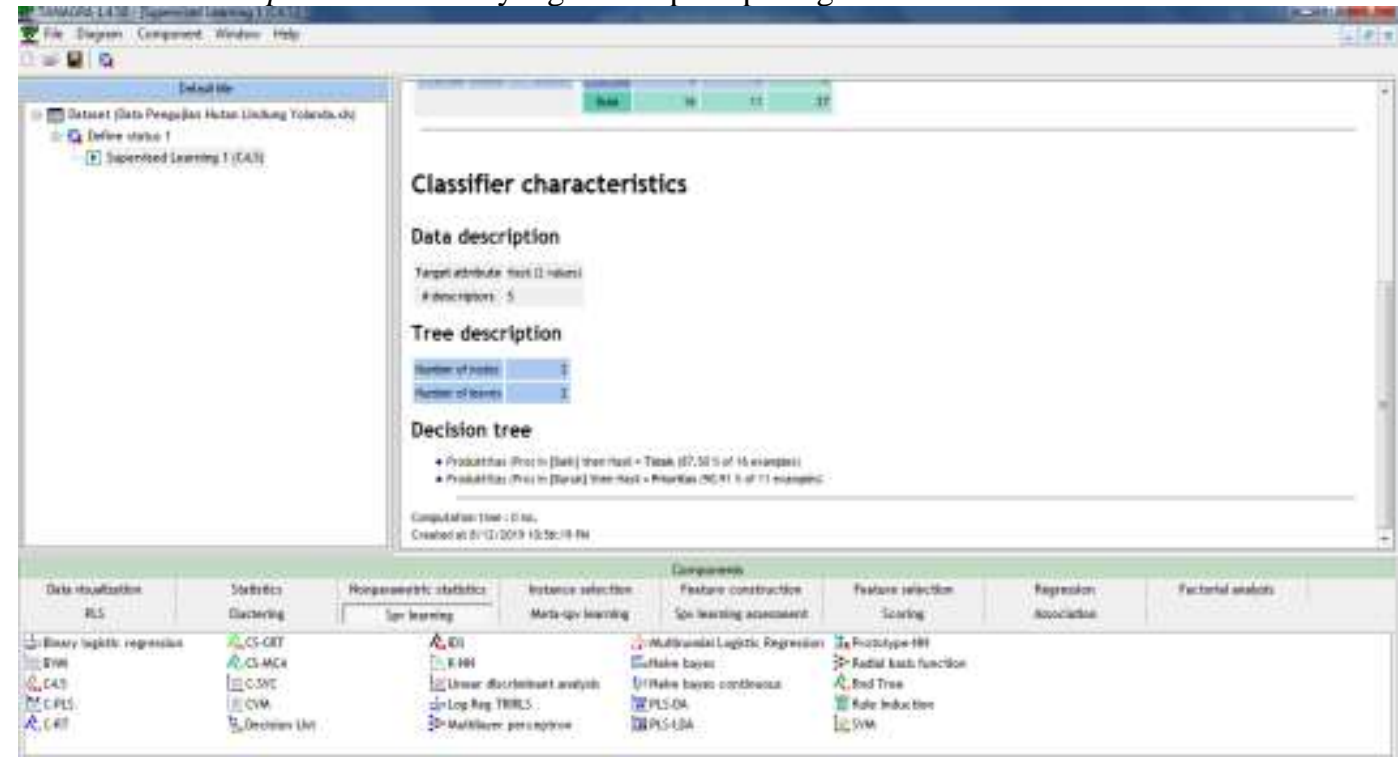

Gambar 3. Hasil Perhitungan Tanagra

Berdasarkan gambar 5.9 hasil decission tree algoritma c4.5 yang didapatkan dari hasil pengujian yang dilakukan tanagra adalah sebagai berikut:

1. Jika Produktifitas Baik maka Hasil Tidak Prioritas (87.50\% of 16 examples)

2. Jika Produktifitas Buruk maka Hasil Prioritas (90.91\% of 11 examples)

Hasil dari analisa menggunakan software tanagra yang menghasilkan informasi dari data yang telah di input, software tanagra tidak dapat membuat pohon keputusan dari hasil decission tree.

\section{KESIMPULAN}

Berdasarkan hasil analisis dan implementasi yang dilakukan dalam penerapan Data Mining untuk pengolahan Data Hutan Lindung Sumatera Utara dengan menggunakan Algoritma C4.5, maka dapat diambil beberapa kesimpulan sebagai berikut:

1. Bedasarkan hasil penyelesaian,Algoritma C4.5dapat mengetahui cara pengelolaan hutan lindung. 
2. Dengan menggunakan Algoritma C4.5 untuk perhitungan dalam mengidentifikasi faktor-faktor penyebab kerusakan hutan lindung, ternyata mampu menyelesaikan permasalahan Dinas Kehutanan Sumatera Utara dalam mengelola data hutan lindung.

3. Pengujian yang dilakukan oleh data mining terhadap aplikasi Tanagra sangatlah mudah dalam mendapatkan inform

\section{REFERENCES}

[1] [Online]. Available: http://dishut.sumutprov.go.id/blog/?page_id=56. [Accessed 12 Mei 2019].

[2] B. Novianti, T. Rismawan and S. Bahri, "Implementasi Data Mining Dengan Algoritma C4.5 Untuk Penjurusan Siswa (Studi Kasus: Sma Negeri 1 Pontianak)," Jurnal Coding, Sistem Komputer Untan, vol. 4, no. 3, pp. 75-84, 2016.

[3] M. Arinda Firdianti, Implementasi Manajemen Berbasis Sekolah Dalam Meningkatkan Prestasi Belajar Sekolah, Yogyakarta: Gre Publishing, 2018.

[4] E. Prasetyo, Data Mining Mengolah Data Menjadi Informasi Menggunakan Matlab, Yogyakarta: Andi, 2014.

[5] D. Nofriansyah, Konsep Data Mining Vs Sistem Pendukung Keputusan, Yogyakarta: Deepublish, 2014.

[6] Kusrini and E. T. Luthfi, Algoritma Data Mining, Yogyakarta: Andi, 2009.

[7] A. S. Sinery, R. Angrianto, Y. Y, Rahawarin and H. F. Peday, Potensi Dan Strategi Pengelolaan Hutan Lindung Wosi Rendani, Yogyakarta: Deepublish, 2015.

[8] I. R. A. M. H. F. P. S. H. M. S. Y. Y. R. S. H. M. S. Dr. Ir. H.M Sumaryono M. Sc, Potensi Dan Pengembangan Hutan Lindung Ayamwaru, Yogyakarta: Deepublish, 2017.

[9] M. Drs. Lamhot Sitorus, Algoritma Dan pemograman, Yogyakarta: Andi, 2015.

[10] Krismiaji, Sistem Informasi Akuntansi, Yogyakarta: UPP AMP YKPN, 2010.

[11] M. Ir. Pandapotan Sianipar, Bekerja Dengan Microsoft Excel 2016, Jakarta: Gramedia, 2018.

[12] Sarwandi, Jago Microsoft Excel 2016, Jakarta: Elex Media Komputindo, 2017.

[13] [Online]. Available: sartika1603.tanagra.com. [Accessed 12 Mei 2019]. 